\title{
Users, information consumers, and information service agencies from the marketing perspective
}

\author{
Usuários, consumidores da informação e unidades prestadoras \\ de serviços informativos na perspectiva de marketing
}

Sueli Angélica do AMARAL'

\begin{abstract}
Marketing perspective in the provision of information services involves information providers, information users, and the context of the information environment. It values the business approach to information service provision for society development and increases the visibility of the breadth and comprehensiveness of Information Science application and usage. The objective of this article is to address concepts related to the marketing perspective in the management of these services with emphasis on the information business and market. The theoretical discussion was based on a literature review on the management of information services from the marketing perspective in the context of information science focusing on the studies carried out by Information Marketing Research Group members and on national and international research on this topic, including classic marketing studies. The present study discusses the actions arising from this perspective of management in information service agencies. It was concluded that the theoretical discussion of the concepts related to the marketing perspective contributed to broaden the understanding of users as information consumers, as well as the theoretical principles of marketing that are related to this approach to the management of information service provision.
\end{abstract}

Keywords: Information business. Information marketing. Information services. Information service agencies. Information unity. Information users.

\section{Resumo}

A perspectiva de marketing na prestação de serviços informativos envolve os prestadores dos serviços, os usuários da informação e o contexto do ambiente informacional, bem como valoriza a visão empresarial da prestação desses serviços para o desenvolvimento da sociedade, além de ampliar a visibilidade da abrangência e escopo de atuação da Ciência da Informação. O objetivo do artigo é discutir conceitos relacionados à perspectiva de marketing na gestão da prestação desses serviços, com ênfase no mercado e no negócio da informação. Busca analisar a discussão teórica, por meio de revisão bibliográfica sobre gestão dos serviços informativos, na perspectiva de marketing no contexto da Ciência da Informação, com ênfase nos estudos desenvolvidos por membros do Grupo de Pesquisa em Marketing da Informação e por autores nacionais e estrangeiros que cuidam da temática, incluindo estudos clássicos de marketing. $O$ presente artigo discorre e comenta as ações decorrentes de tal perspectiva de gestão em unidades prestadoras de serviços informativos. Conclui que a discussão teórica sobre os conceitos relacionados à perspectiva de marketing contribui para ampliar o entendimento dos usuários como consumidores da informação, bem como para aprofundar o conhecimento sobre os princípios teóricos de marketing na prestação de serviços informativos.

Palavras-chave: Negócio da informação. Marketing da informação. Serviços de informação. Unidades prestadoras de serviços informativos. Unidades de informação. Usuário da informação.

\footnotetext{
1 Universidade de Brasília, Faculdade de Ciências da Informação, Programa de Pós-Graduação em Ciênciada Informação. Campus Universitário Darcy Ribeiro, Edifício da Biblioteca Central, Entrada Leste, 70910-900, Brasilia, DF, Brasil.E-mail:<samaral@unb.br>.

Support: Conselho Nacional de Desenvolvimento Científico e Tecnológico (Process: 312411/2013-8).

Recebido em 10/6/2015, reapresentado em 21/10/2015 e aprovado para publicação em 17/5/2016.
} 


\section{Introduction}

The provision of information services faces uncertainties caused by the rapid pace of changes in the economic, institutional, and technological environments. This reality gives rise to new business models that will enable well-prepared companies to prosper and those that are not able to adapt will go out of business, according to Amaral (2009), who was referring to the statement of Tapscott and Williams (2007, p.22, our translation): "Individuals now share knowledge, computing power, bandwidth, and other resources to create a wide range of free and open source goods and services that anyone can use or modify".

In the international arena of Information Science, many scholars have defended and valued the contribution of marketing strategies to libraries and other information service providers. Among them are (a) Darlene E. Weingand, professor emeritus at the University of Wisconsin, Madison, USA and author of "Future-driven library marketing (1998), Customer service excellence: a concise guide for librarians (1997)" and "Marketing/ planning library and information services (1987)"; (b) Blaise Cronin, professor emeritus of Information Science at Indiana University, Bloomington (IN), United States, edited"The marketing of library and information services (1981)"; (c) Jennifer Rowley, Edge Hill University, Ormskirk (UK), author of "Information Marketing (2006)"; (d) Christie Koontz, School of Information, Florida State University, Thalahasse (FL), United States, co-authored "Key publications in library marketing (2006)" with Dinesh Gupta, Vardhaman Mahaveer Open University, India, and Sheila Webber, London Metropolitan University (UK); Christie Koontz and Lorri Mon, who wrote"Marketing and social media: A guide for libraries, archives, and museums (2014)"; (e) Dinesh Gupta, who edited "Marketing Library and Information Services: International perspectives (2006)"; in 2011, he co-edited "Marketing Libraries in a Web 2.0 world" with Réjean Savard, Université de Montreal, Canada, and in 2013, he wrote a chapter on the "Role of IFLA in marketing Initiatives in Library and Information Services" in the book titled "Collaboration in (f) Réjean Savard, who wrote "Directrices para la enseñanza de la comercialización en la formación de bibliotecarios, documentalistas y archiveros", published by United Nations Educational Scientific and Cultural Organization (Unesco) in 1996.

In order to highlight Brazilian researchers who have highlighted the contribution of marketing in the context of Information Science, a search was conducted in the Lattes Platform in the Research Groups Directory of Conselho Nacional de Desenvolvimento Científico e Tecnológico (CNPq) to identify existing research groups in June 2009 and in August 2013. The search term used was 'marketing' and the search results were compared. In 2009, there were a total of 190 research groups; in 2013, this number reached 267. The search was narrowed using the term 'information marketing', and 37 groups were identified in 2009; three of them worked in the area of Information Science. Although in 2013 the number of groups reached the total of 47 , the number of groups working in the area of Information Science remained unchanged. The term 'marketing' was identified in the research lines of the three groups, but the title of one the groups was Grupo de Pesquisa em Marketing da Informação (GPMI, Information Marketing Research Group). This Group was composed of 10 members, and its records indicated the group interest in confirming the theory on the planning, management, and assessment of marketing in libraries and information service agencies in the private and public sectors. The group emphasizes the principles and possible theoretical dialogues to represent the marketing perspective in the management of information services. This finding revealed the existence of a small scientific community working on the theory of marketing in the management of the provision of information services, which can be seen as a matter of concern.

The dialogue between the areas of knowledge extends the possibilities of the rather different theoretical, conceptual, and methodological contributions. In terms of Information Science, the marketing perspective in the management of information service provision involves information agencies, information users, and the context of the information environment by valuing the business approach to information service provision for society development, increasing the visibility of the breadth and comprehensiveness of Information Science application and usage. 
According to Amaral (2011), from the viewpoint of information marketing, the commitment to offer services demands interest and concern about the users' satisfaction of the services they receive, message adequacy, media, costs, and easiness of technological communication in order to establish and maintain relationships (two-way street) between those who demand (users) and those who provide information (Unidades Prestadoras de Serviços Informativos, UPSI [Information Service Agencies]). The author argues that this innovative form of management leads to a greater visibility of the UPSI activities in the information business area in which its maintainer operates, and it contributes to highlight the aggregated value of the services provided.

Therefore, the objective of this study is to address concepts related to marketing perspective in the provision of information services with emphasis on the management of these services in the information market and business.

\section{Methodological procedures}

This article investigates the marketing perspective in the management of information services to broaden the understanding of the management activities in the service provision environment in order to contribute to the development of its theoretical framework.

The theoretical discussion was based on the literature review on the management of information services from the marketing perspective in the context of Information Science. In the Brazilian literature, the studies carried out by the GPMI members, which were retrieved from the search for the group members' curriculum vitae conducted in October 2014 in the Lattes Platform (CNPq), stand out. This limitation is justified by the search conducted in the Research Group Directory of this Platform in August 2013, indicating that the Brazilian Information Science scientific community interested in this topic is small and restricted to the GPMI.

Some classical studies highlighting the conceptual transposition of the principles of marketing in the for-profit sector to be applied in nonprofit organizations were also selected. Among the studies on the use of marketing concepts in information services, the literature review conducted by Garaufallou et al. (2013), professors in the Department of Library Science and Information Systems at the Alexander Technological Educational Institute of Thessaloniki, Greece, was selected.

The results of the theoretical and conceptual analysis are presented in the marketing perspective in the context of Information Science. Concepts related to information service agencies and their public were addressed. These concepts concern users as consumers of information and emphasize the use of marketing in the management of information service provision in the information market and business.

\section{Information service agencies and their public}

Although well-known in the Information Science literature, a consensual definition of the term 'information unit', has not yet been provided by researchers in this area. Guinchat and Menou (1994) used the term to refer to sectors of businesses that serve the following mission: to identify, as accurately as possible, all information of potential interest to users, help them retrieve corresponding documents, and answer their questions. However, these authors did not state whether libraries could also be considered an 'information unit', but this doubt has been cleared up by the definition of 'information unit'given below,

[...] all types of organization in the area of information and/or documentation working with records of knowledge in any type of support, regardless of their designation. Information units are all types of libraries, map libraries, center/ service/department/information system and/or documentation, according to their scope and operation (AMARAL, 1998, p.15, our translation).

Sampaio (2010) argues that there is a tendency towards using the term 'information unit' as a synonym for library in the Library Science literature and added that other authors use 'information unit' as a generic term to identify different types of libraries and justify the use "as libraries broaden their scope in terms of the management of stored information to encompass not only physical media (books/paper) but also electronic, digital, and virtual media" (p.17, our translation). 
The term library does not correspond to the reality of contemporary society anymore; however, from the marketing perspective, the traditional library, either hybrid or digital, and/or the 'information unit' can be studied as organizations subjected to impacts of the environment in which they operate, determined by the institution or corporation that maintains the library. Regardless of its denomination and the scope of services provided in the private or public sector, this study addresses the UPSI that is involved in the provision of information and/or information services, which justifies the use of this acronym in Portuguese. It is worth mentioning that in Portuguese the word 'unit' (unidade) is part of the name (information unit) that designates this type of information agency.

Whether or not the UPSI maintainer is a profit organization, is not important. Despite the origin of marketing in the profit sector, Kotler and Levy (1969) addressed the conceptual transference of marketing to nonprofit organizations. Therefore, from the marketing perspective, the UPSI as an information service agency can adapt to the concepts related to its public in different classifications.

According to Kotler et al. (2002) public is a specific group of people and/or organizations that have an actual or potential interest and/or impact on an organization. This definition encompasses companies in general, and the authors highlight that "all professional service providers have a diversified public, and they need to manage interactive relationships with most of them" (KOTLER, 2000, p.157, our translation). They categorize the different types of public according to their appeal and importance to a particular organization, as follows: (a) mutually welcome public: those that like the organization and appreciate the service received; (b) intended public: those that the organization wants to reach but are indifferent or have a negative attitude towards the organization; (c) undesirable public: those that maintain a negative attitude towards the organization and try to impose restrictions, exert pressure, or exercise control over the organization.

It is unlikely that a public library will deny service assignments. They will certainly be serviced but will be considered as undesirable public because they are not part of the university community, the target audience of an academic library. Therefore, the classification of different types of public presented can be adapted to the UPSI aiming to better understand the diversity of the public to be served.

In another classification, according to the functional relationship established with the maintainers, Kotler et al. (2002) proposed four types of public:

1) Input Public generate resources and can impose restrictions on the organization - supplier public: provide goods and services required by the main activity of an organization; outsourced providers: hire and pay for services on behalf of an organization; regulatory groups: entities that impose codes of conduct upon the organization.

2) Internal Public is the organization staff who deals with the various inputs to accomplish the organizational mission: managers (responsible for the organization administration), board of directors (may or may not exist; the board president and the administrators oversee the organization aimed at achieving its goals) and employees (responsible for the services of the organization).

3) Intermediary Public assist in the promotion and distribution of goods and services offered by the organization to the final consumers; there are of four types: distributors (wholesalers and retailers who buy and sell goods); facilitators (transport, communication, and real estate companies: assist in the distribution of goods and services or messages but do not take ownership or trade products); agents (companies or persons who locate and/or offer the products or services of the organization to third parties without taking ownership of them) and; marketing companies (advertising agencies, market research companies, and marketing consulting firms that help identify, develop, and promote the organization's products and services in certain markets).

4) Consuming Public are the various groups that use the products and/or services offered by the organization: clients (represent the primary target audience and the primary purpose of any organization); 
local public (neighborhood residents and community organizations); activist public (consumer organizations and business groups that aim to win concessions or support for certain causes); general public (professional service providers should be interested in the public attitudes as a whole based on their activities and policies. The general public may not have organized influence on organizations such as that of the activists, but they may hold a bad image of organizations affecting them in terms of obtaining sponsorship and legislative support); means of communication (including vehicles used to disseminate news, stories, and editorial opinions, more specifically newspapers, magazines, and radio and television stations).

The identification of the different types of public is essential because not all of them are important to an organization. The classification of the public according to the functional relationship with the maintainer can be adapted to the UPSI because,
[...] the organization is considered as a resource converter; the inputs generated by the supplier public are converted by the internal public into goods and desired services, which, in turn, are delivered to specific consumers by the intermediary public (KOTLER et al., 2002, p.157, our translation).

The functional relationship of the UPSI with its public can be seen in Figure 1. It can be seen that the users are included in the group that represents the UPSI output, from a systemic perspective of the functional relationship between the provider and the consumers, to whom the products and services are intended. Among the consuming public are: the clients, general public, activist public, local public entities, means of communication, and competitors. It should be noted that although everyone can consume products and information services, it is common to use the term user as the recipient of the information provided. Each UPSI can expand the identification of the public included in

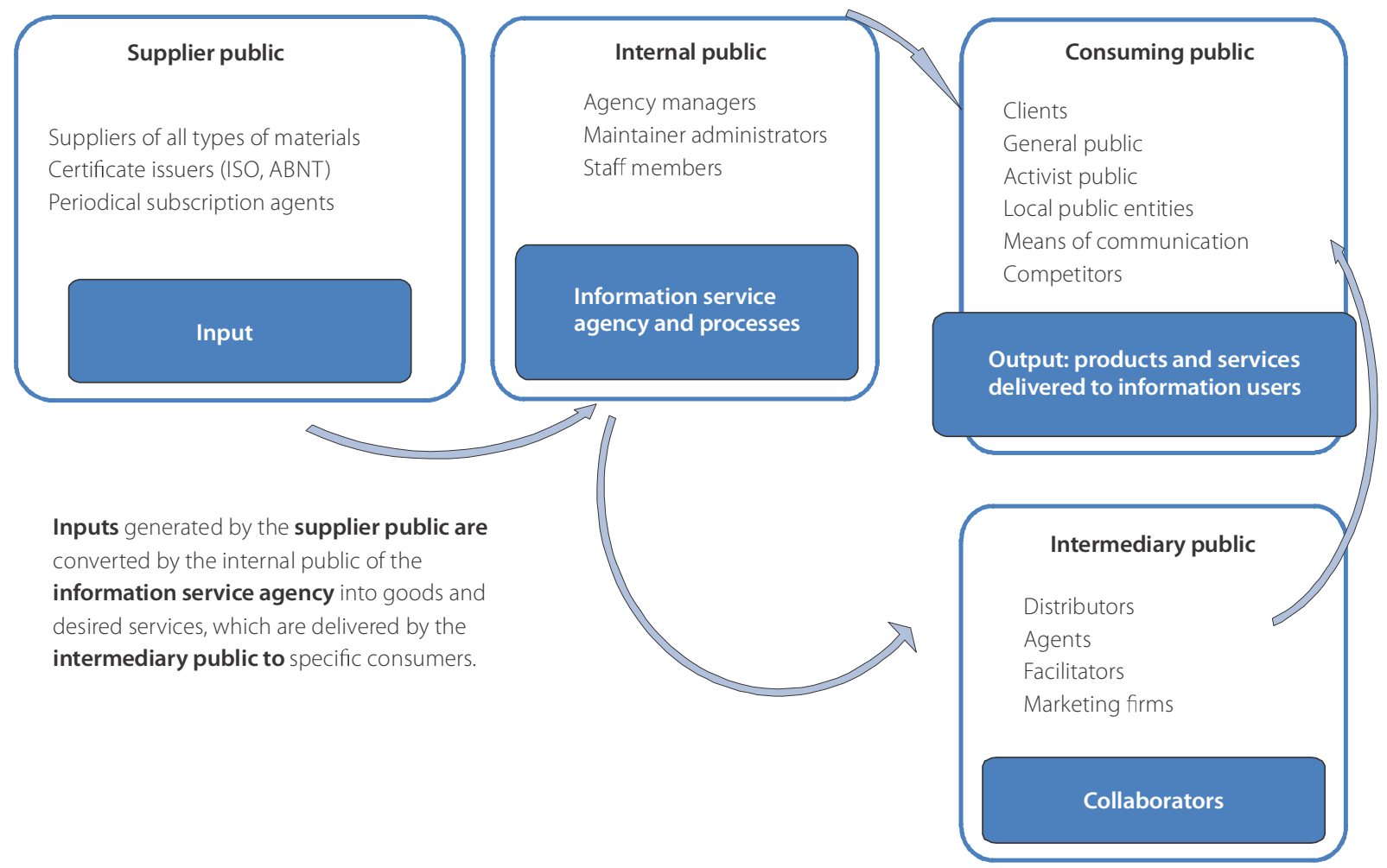

Figure 1. Types of public according to the functional relationship with the information service agency. Source: Prepared by Amaral based on Kotler et al. (2002, p.158). 
this classification aiming at better understanding them when defining the service and the relationship to be established with each public segment identified and their priorities in the context in which the UPSI operates. This marketing perspective of the user as an information consumer can contribute to improve information service provision and increase the visibility of the breadth and comprehensiveness of Information Science application and usage.

\section{Users as information consuming public}

In a study on the analysis of Brazilian consumers in the information sector, Amaral (1996) advocated the adoption of marketing techniques to investigate users and better understand them, considering the cultural, social, psychological, and political aspects of their profile as information consumers in the context of Brazilian reality of information service provision. The author recommended applying it more often and in a more conscious way, considering the user's point of view and concluded that the adoption of the techniques of analysis, research, and market segmentation, as well as consumer analysis, contributed to the improvement of the study of users as instruments of planning and management. Amaral (1996)'s proposal has been evaluated and used in unpublished academic papers, but it has not yet been fully considered for the provision of information service to information users.

Rozados and Piffer (2009) revealed and explained the conceptual similarity between marketing and information management by highlighting the history, evolution, and characteristics of marketing research and user studies. They concluded that both provide data that allow the evaluation of existing information services and products, the knowledge about competitors and their offerings, and the proposal of new services and products that could fulfill the needs and demands of users/ customers.

In business administration, the term client refers to both the end user/consumer of the product or service and the external customer. The staff member responsible for the development and promotion of a product and/ or service can be considered an organization's internal client. However, in the UPSI, the term client is rarely adopted and the term consumer is not commonly used.
Among several review articles on users, Pinheiro (1982) highlights that the article carried out by Taube (1958) was one of first studies [...] to distinguish consumer services from professional services seeking to identify the reasons for failure and questions the validity of these pioneering works as a guide for the improvement of information services (PINHEIRO, 1982. p.14, our translation).

Pinheiro (1982) also discussed two other studies addressing information consumption that were published in 1977. One of them, Ljungberg (1977), investigated the need for information in research organizations and evaluated the balance between the needs of users and information consumption. The other one was the article by Allen (1977), who addressed information consumption patterns in research and development projects.

Analyzing the use of the words'user'and 'client' in the context of Library Science, Lunardelli (2004, p.97, our translation) concluded that,

[...] although they apparently denote the same subject, there are important differences in meanings between them.' 'User'indicates the act of using or utilizing something, whereas the word 'client' is related to the idea of relying on someone to get or have access to something.

According to Lunardelli (2004, p.92, our translation), some Information Science researchers consider that "user has a more passive connotation than client". The author adds that those who adopt the term 'user' value the service provider only, whereas the 'user' "would be someone who uses a particular service simply because there is no alternative", and the term 'client' "would be someone who wants and/or searches for a specific product or service". The author points out that "other researchers in this field consider the use of 'client' as inappropriate", by stating that this "word is linked to the concept of customer and, as such, it would be someone who usually buys or sells from a certain store".

Dantas (2014) states that we are all consumers, but not all of us are clients. However, if the organization providing service to us expresses interest in keeping us as consumers by offering us incentives so that we become loyal, we tend to become clients. We move from regular consumers, due to the fact we identify with the organization or to the advantages offered, to clients. 
Although the consumer of products can be simply called 'consumer' and the consumer of services can be called 'user', the rights and responsibilities of consumers, clients, and users are the same. This may justify the indiscriminate use of these terms by authors in different areas. In the business environment whose goal is to make a profit or in UPSIs, the terms used are 'client', 'consumer', or 'information user', and the organizations cannot exist without them.

Izquierdo Alonso (1999) argued that the user is the one that has received other denominations: reader, recipient, information receiver, client, information consumer, internal/external user, and real/potential user among others.

Pérez Giffoni and Sabelli (2010, p.20, our translation) define user as:

The person that is direct or potentially related with the information resource; social actor of a reality that is in constant change and conflict; an individual that due to all of his/her subjectivity, cultural capital, and view of reality can be socially constructed in the encounter with the other in a dialectical relationship with his/her world. Thus, this results in the practices of a consumer and information producer, the methods that the individual uses to find and access information sources, and the individual interactions with computer information systems.

A study on the effects and perspectives of the use of electronic information addresses changes in users' habits, defines their role as consumers and producers of information, and shows that

In the context of Library Science and Information Science, fads, ideologies, concepts, and terminology imported from the Economics, Business, business logic, finances, and market laws' world lead to the fact that by facing a problem or taking on a concrete task, we go into detail and relate their role to the whole and do not see that we are inserted in an ever-changing reality and that we can contribute to change it (PÉREZ GIFFONI; SABELLI, 2010, p.20, our translation).

Blattmann and Silva (2007) emphasize that Bellei (2002) uses the term 'lautor' to refer to the reader who becomes an author by interacting, modifying, and creating new texts in particular contexts, in addition to allowing to share ideas and ideals with other Internet users. Thus, there is vast increase in data, information, and knowledge.

Although there are different approaches to information consumption, the term information consumer is not commonly used, indicating the need for a model grounded on theory and methodology to analyze and distinguish the user as an information consumer.

The classification of individuals in the consumer markets proposed by Kotler (2000) can also be used to classify individuals as users and consumers of information obtained from information services. This can be done by replacing 'product/service/idea/cause' with'information service' in the following hierarchical levels of Kotler's classification: (a) suspect: a person who fits the profile of the public with potential level of interest in the product/ service/idea/cause; (b) prospect: one who knows the product/service/idea/cause; (c) consumer: one who has consumed at least once the product/service or has supported at least once an idea/cause; (d) client: one who consumes the product/service again or supports the idea/cause again; (e) brand advocate: the person who consumes the product/service/idea/cause with a certain frequency.

Dantas (2006, p.54, our translation) argued that the "relationship marketing to build relational learning between the organization and its clients, prospects, and suppliers results in gaining advantage over competitors". According to the author:

It is difficult to agree with the statement that clients do not know what they want. They do know. It may sometimes happen that they do not know how to verbalize what they want. Thus, it depends on the questions posed to the client. Obtaining information from someone requires knowing how to ask for it (DANTAS, 2006, p.51, our translation).

Information users are highly diversified, which justifies the diversified terminology used to refer to them. Cunha et al. (2015, p.20, our translation) stated that "it is not a coincidence that the entry of the word'user' in the Dictionary of Library Science and Archivology compiled by Cunha and Cavalcanti $(2008$, p.372) is two pages long".

The theoretical and conceptual analysis conducted shows that the marketing theories can aggregate value 
to studies addressing the opinions of information users since this theory is focused on identifying consumer interests and desires to develop products and services that can satisfy the identified demand. Even if there are conflicting opinions about the importance of user studies as tools for the planning and management in marketing perspective to provide useful information to those who use or consume it, it is important to understand who wants to receive the information and how they want it.

The management of the information service provision environment with business approach to information market and business should be investigated by Information Science researchers to demonstrate the importance of the theoretical approach to marketing concepts in this area.

\section{Marketing in the management of information service provision in the information market and business}

Based on the studies of Bushing (1995), Arachchige (2002), Blackstead and Shoaf (2002), Garaufallou et al. (2013) highlighted that marketing helps an organization in terms of product quality and service development processes considering the clients' needs on the front end to increase awareness of products and services and their use. Moreover, based on Besant and Sharp (2000), Martey (2000), Schmidt (2006) and Andreasen and Kotler (2007), the authors argued that marketing can provide a wide variety of useful tools to determine and evaluate the adequacy of products and services.

In Brazil, the Information Marketing Research Group states that the dialogue between the areas of knowledge represents a great advance in the marketing perspective in information management in the UPSI and presupposes a change in the professional attitude in the context of Information Science. Understanding this premise facilitates seeing the UPSI as an organization engaged in the information business. It is important to know the organizational structure since it defines how its activities are carried out in alignment with the business area of its maintainer.

In 1960, Theodore Levitt argued that the shortsighted approach management prevents many companies from properly defining their market opportunities, a view that made his article a true classic. "Marketing Myopia" is recommended as the best introduction to understand that, in order to thrive, every business needs to have a complete view of the type of business it is in, but the limitation on the executives' perception of their own business is a major problem. The author said that,

Every major industry was once a growth industry. But, some that are now riding a wave of growth enthusiasm are very much in the shadow of decline. Others which are thought of seasoned growth industries have actually stopped growing. In every case, the reason growth is threatened, slowed, or stopped is not because the market is saturated. It is because there has been a failure of management (LEVITT, 1960, p.45).

In his article, Levitt (1960) discussed two examples. He pointed out that at that time the railroads did not stop growing because the need for passenger and freight transportation declined. In the author's opinion, the need for transportation increased, and this need was filled by other means (cars, trucks, airplanes, and even telephones) and not by the railroads themselves. They lost customers because they assumed they were in the railroad business, rather than in the transportation business. They defined their industry incorrectly because they were productoriented instead of customer-oriented.

The other example highlighted by Levitt (1960) was when the film companies of that time went through drastic reorganizations and Hollywood barely escaped being totally ravished by television. Some companies closed due to what the author called myopia in terms of defining their own business. Hollywood thought it was in the movie business when it was actually in the entertainment business. If Hollywood had been customer-oriented (providing entertainment), rather than product-oriented (making movies) it would not have gone through difficult times. What saved Hollywood and was responsible for its resurgence was the wave of new young writers, producers, and directors who were successful in television.

Levitt (1960, p.47) stated that "The history of every dead and dying 'growth' industry shows a self-deceiving cycle of bountiful expansion and undetected decay". Adapting the author's ideas to the 
information environment, we have: (a) The belief that there will always be public to use libraries as a result of population increase is wrong. Perhaps because its existence as an information service agency can be substantiated and justified by the fact that libraries are considered a good cause to be defended and because people refer to the library as something intrinsically good with social value. Although unquestionable, this is not sufficient to guarantee the frequency pattern of library usage; (b) The belief that there is no competitive substitute for the major product/service/information of each library may be due to the fact that in the information environment, it is common to assume that competition is an unacceptable idea because library operation is based on information sharing, traditionally offered free of charge; (c) Too much faith in the product offer and provision of routine information services with the traditional pattern of mass production and generalized gratuity contribute negatively to the poor performance of libraries; (d) The concern regarding offering information as a product of excellence, due to the importance of the information itself, can lead libraries to neglect assistance to users and the relationship with them when providing services.

This reality shows that a clear understanding of information business is necessary. Figure 2 shows various information market social actors to better understand the information business that include the UPSI responsible

\section{INFORMATION BUSINESS}

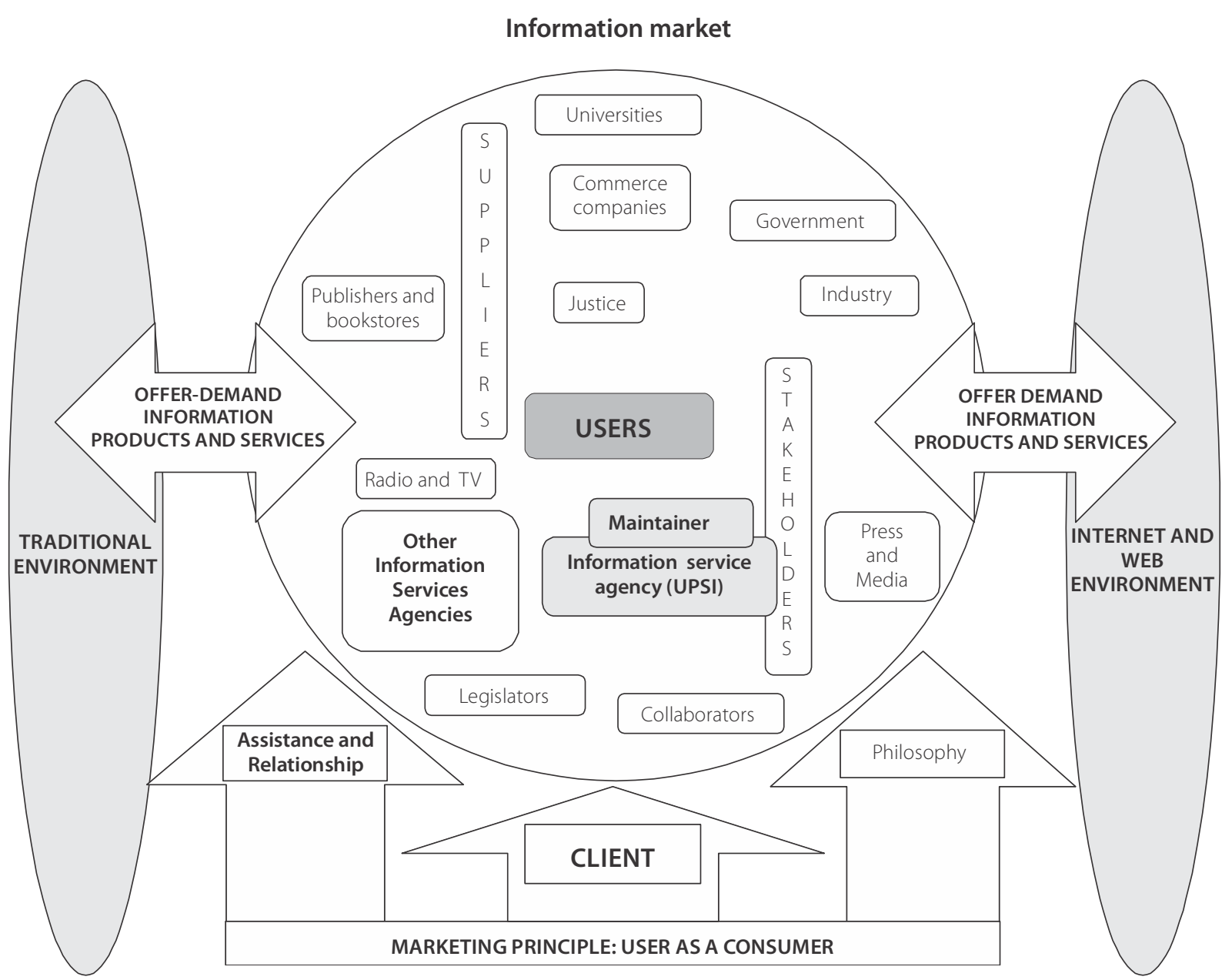

Figure 2. Information market and business.

Source: Amaral (2013). 
for offering products and providing information services in the traditional environment and on the Internet. This offer must adequately fulfill users' demand based on the identification of their requirements as information users/ consumers.

This figure highlights the marketing principles: (a) concern about the assistance provided (positive reaction to criticism, complaints, and suggestions), dissemination of benefits derived from the adoption of marketing approach, with an emphasis on the relationship between the UPSI and its public; (b) development of strategies focused on the client (user as information consumer); (c) commitment to the philosophy, concept, or marketing mentality adopted by the management.

Addressing concepts related to information users, information service agencies, and information environment from a marketing perspective, can stimulate the development of theoretical and conceptual framework and research on Information Science focusing on the contribution of the provision of these services to the development of society.

The marketing perspective is essential for this purpose, but the management of the information service provision requires a business approach to the information market and business to increase the visibility of the breadth and comprehensiveness of Information Science application and usage.

\section{Conclusion}

Faced with the challenge of the traditional information environment and the Internet environment in terms of providing satisfactory information services to the users (information consumers), the UPSI should be able to lead the constantly changing information market and business. Aware of this commitment and the social responsibility to contribute to the development of society, a theoretical analysis of the concepts related to the marketing perspective in the management of information services is essential to understand the theoretical principles of the marketing philosophy.

This reality also helps information service agencies understand the marketing principles because the management from this perspective seeks to intensify loyalty, improve customization and personalization, strengthen relationships through interactions; allow the creation of communities for members to share common interests; and foster the participation of the user/client/ consumer in collaborative networks using laptop, palmtop, pager, fax, e-mail, video conference and other means and electronic channels available to develop effective communication with the UPSI.

The aforementioned discussions highlighted the marketing perspective in the business approach to the provision of information services of UPSIs emphasizing their value in the assistance and relationship with users as the information consumers in the specific information market and business in which their maintainers operate.

Although there has been increasing interest in the marketing teachings among Information Science professionals and researchers, the theoretical aspects to support this approach in the context of this field are still scant. Consequently, the theoretical framework of the adoption of the concept, mentality, or marketing philosophy by Brazilian professionals in the management of the provision of their information services can be influenced by this theory scantiness.

Theoretical and conceptual studies addressing this topic from the marketing perspective can significantly contribute to increase the visibility of the breadth and comprehensiveness of Information Science application and usage. Moreover, the discussion of concepts related to the users and information service agencies in the context of information environment from a marketing perspective allows valuing the provision of these services for society development.

However, the marketing perspective in the management of information services in the context of Information Science needs to be further investigated and disseminated in Brazil. Professionals working in UPSI need to be better prepared to deal with the issues raised by users and should improve their relationship with this type of public. Enhancing the visibility of the activities carried out is necessary to provide information services that meet the requirements of information users. The marketing perspective of the management of these services seeks the understanding of the business approach when the theoretical framework of this perspective shows the importance of the principles of marketing in the information market and business in the area in which the UPSI maintainer operates. 
Furthermore, the most important contribution of the theoretical and conceptual analysis from the marketing perspective is not limited to the proposed change in the terminology related to the 'users' of information. The major contribution is related to the change in attitude towards the understanding of the marketing principles to expand the view of the management of the provision of information services. In other words, it is related to understanding the benefits of this knowledge as a theoretical and conceptual contribution of the business approach to be applied to the specific requirements of the professional practice in the information market and business in which the UPSI is inserted. Therefore, the users can be understood as customers and/or clients even if they are still called information users.

\section{Acknowledgments}

The author thank the Conselho Nacional de Desenvolvimento Científico e Tecnológico that made possible the publication of the article.

\section{References}

ALLEN, T.J. The role of person to person communication network in the dissemination of industrial technology. Cambridge: Institute of Technology, 1977.

AMARAL, S. A. Análise do consumidor brasileiro do setor de informação: aspectos culturais, sociais, psicológicos e políticos. Perspectivas em Ciência da Informação, v. 1, n. 2, p. 207-224, 1996.

AMARAL, S. A. Marketing: abordagem inovadora para entender o mercado e o negócio da informação. Ciência da Informação, v. 40, n. 1, p. 85-98, 2011.

AMARAL, S. A. Marketing: abordagem em unidades de informação. Brasília: Thesaurus, 1998.

AMARAL, S. A. Marketing e valores bibliotecários. In:ESCALONA L. (Coord.). Mercadotecnia y valores: ¿contradicciones en la educación bibliotecológica? México: Universidad Nacional Autonoma de México, 2013.

AMARAL, S. A. El professional de la información para el Siglo XXI. Infodiversidad, v. 14, p. 11-27, 2009.

ANDREASEN, A. R.; Kotler, P. Strategic marketing for non-profit organizations. $7^{\text {th }}$ ed. Upper Saddle River: Prentice-Hall, 2007.

ARACHCHIGE, J. J. G. An approach to marketing in special and academic libraries of Sri Lanka: A survey with emphasis on services provided to the clientele. 2002. Available from: $<$ https:// core.ac.uk/download/pdf/11878943.pdf? repositoryld=418>. Cited: June 6, 2015.

BELLEI, S. L. P. O livro, a literatura e o computador. Florianópolis: EdUFSC, 2002.

BESANT, L. X:; SHARP, D. Libraries need relationship marketing: Mutual interest marketing concept, embraced by many companies, also needed by libraries. Information Outlook, v. 4, n. 9, p. 17-22, 2000.

BLACKSTEAD, K. J.; SHOAF, E. C. Synergy in library public relations, marketing, and development activities. In: KARP, $R$. S. (Ed.). Powerful public relations: A how-to guide for libraries. Chicago: American Library Association, 2002. p. 1-7.

BLATTMANN, U.; SILVA, F. C. C. Colaboração e interação na web 2.0 e biblioteca 2.0. Revista ACB: Biblioteconomia em Santa Catarina, v. 12, n. 2, p. 191-215, 2007.
BUSHING, M. C. The library's product and excellence. Library Trends, v. 43, n. 3, p. 384-400, 1995.

CRONIN, B. (Ed.). The marketing of library and information services. London: ASLIB, 1981.

CUNHA, M. B.; AMARAL, S. A.; DANTAS, E. B. Manual de estudos de usuários da informação. São Paulo: Atlas, 2015.

CUNHA, M. B.; CAVALCANTI, C. R. Dicionário de biblioteconomia e arquivologia. Brasília: Briquet de Lemos, 2008.

DANTAS, E. B. Gestão da informação sobre a satisfação de consumidores eclientes: condição primordial na orientação para o mercado. São Paulo: Atlas, 2014.

DANTAS, E. B. A informação como insumo na prática do marketing: possibilidade de capturar o conhecimento do cliente. Informação \& Sociedade: Estudos, v. 16, n. 1, p. 47-64, 2006.

GARAUFALLOU, E. et al. The use of marketing concepts in library services: A literature review. Library Review, v.62, n.4/5, 2013.

GUINCHAT, C.; MENOU, M. Introdução geral às ciências e técnicas da informação e documentação. Brasília: IBICT, 1994.

GUPTA, D. (Ed.). Marketing library and information services: International perspectives. München: K.G. Saur, 2006.

GUPTA, D.: SAVARD, R. Marketing libraries in a web 2.0 world. Berlin: De Gruyter Saur, 2011. (IFLA Publications, 145).

GUPTA, D.; SAVARD, R. Role of IFLA in marketing initiatives in Library and Information Services. In: CHAKRABORTY, S.; KUMAR DAS, A. (Eds.). Collaboration in international and comparative librarianship. Hershey: IGI Global, 2013.

IZQUIERDO ALONSO, M. Una aproximación interdisciplinar al estudio del usuario de información: bases conceptuales y metodológicas. Investigación Bibliotecológica, v. 13, n. 26, p. 112-124, 1999 .

KOONTZ, C.; GUPTA, D.; WEBBER, S. Key publications in library marketing. IFLA Journal, v. 32, n. 3, p. 224-231, 2006.

KOONTZ, C.; MON, L. Marketing and social media: A guide for libraries, archives, and museums. Lanham: Rowman \& Littlefield, 2014 
KOTLER, P. Administração de marketing. São Paulo: PrenticeHall, 2000.

KOTLER, P.; HAYES, H.; BLOOM, P. N. Marketing de serviços profissionais: estratégias inovadoras para impulsionar sua atividade, sua imagem e seus lucros. São Paulo: Manole, 2002.

KOTLER, P., LEVY, S. J. Broadening the concept of marketing. Journal of Marketing, v. 33, n. 1, p. 10-15, 1969.

LEVITT, T. Marketing miopia. Harvard Business Review, p. 45-56, 1960.

LJUNGBERG, S. Investigation on the use of information in R\&D in a research intensive company. In: ASIS ANNUAL MEETING, 40., Chicago, Illinois, Sept. 26-Oct. 1, 1977. Proceedings... New York: American Society for Information Science, 1977. v. 14, p. 12.

LUNARDELLI, R. S. A. Usuários ou clientes de bibliotecas? Uma reflexão do ponto de vista da Lexicologia. Signum: Estudos da Linguagem, v. 7, n. 2, p. 91-99, 2004.

MARTEY, A. K. Marketing products and services of academic libraries in Ghana. Libri, v. 50, n. 4, p. 261-268, 2000.

PÉREZ GIFFONI, M. C.; SABELLI, M. Los estudios de usuarios de información: construcción de una línea de investigación y docencia en el Uruguay. Montevideo: Escuela Universitaria de Bibliotecología y Ciencias Afines, 2010.

PINHEIRO, L. V. R. Usuário: informação: o contexto da ciência e tecnologia. Rio de Janeiro: LTC, 1982.

ROWLEY, J. Information marketing. Aldershot: Ashgate Publishing Limited, 2006.
ROZADOS, H. F.; PIFFER, B. P. Pesquisa de marketing e estudos de usuários. Em Questão, v. 15, n. 2, p. 169-182, 2009.

SAMPAIO, L. A. C. Mapeamento das competências gerenciais necessárias aos gerentes das unidades de informação dos Tribunais Superiores do Poder Judiciário Brasileiro. 2010. Dissertação. (Mestrado em Ciência da Informação) - Faculdade de Ciência da Informação, Universidade de Brasília, Brasília, 2010.

SAVARD, R. Directrices para la enseñanza de la comercialización en la formación de bibliotecarios, documentalistas y archiveros. Paris: Unesco, 1996.

SCHMIDT, J. Marketing library and information services in Australian academic libraries. In: GUPTA, D. K. et al. (Ed.). Marketing library and information services: International perspectives. München: IFLA, 2006. p. 120-131.

TAPSCOT, D.; WILLIAMS, A. D. Wikinomics: como a colaboração em massa pode mudar o seu negócio. Rio de Janeiro: Nova Fronteira, 2007.

TAUBE, M. An evaluation of use studies of scientific information. Washington (DC): Documentation Inc., 1958

WEINGAND, D. E. Customer service excellence: A concise guide for librarians. Chicago: American Library Association, 1997.

WEINGAND, D. E. Future-driven library marketing. Chicago: American Library Association, 1998.

WEINGAND, D. E. Marketing/planning library and information services. Littleton: Libraries Unlimited, 1987. 